\title{
PENERAPAN MEDIA GELAS ANGKA DALAM PENGEMBANGAN KEMAMP UAN KOGNITIF ANAK MENGENAL LAMBANG BILANGAN 1-10
}

\author{
Wiwi Umaternate1, Haryati2 ${ }^{2}$, Nurhamsa Mahmud ${ }^{3}$ \\ Universitas Khairun Ternate \\ Fakultas Keguruan dan Ilmu Pendidikan
Jl. Bandarah Sultan Baabullah Kota Ternate Utara, Kotak Pos 53 Ternate 977328
Telepon: (0921) 3110905-Faksimili 0921-3110901

Email: umaternatewiwi194@gmail.com¹, nurhamsaaca@gmail.com²

haryati.mansyur@gmail.com ${ }^{3}$

\begin{abstract}
Abstrak: Penerapan media gelas angka dalam pengembangan kamampuan kognitif anak mengenal lambang bilangan 1-10 merupakan penelitian yang bertujuan untuk mengembangkan pemahaman anak dalam mengenal bilangan 1-10. Kemampuan mengenal lambang bilangan merupakan kemampuan dasar yang harus dikuasai oleh anak. Hal ini merupakan modal awal bagi anak untuk mengenal hal-hal penting dalam kehidupan sehari-hari khususnya yang berhubungan dengan bilangan. Anak mampu mengenal waktu atau jam, tanggal, bulan, serta tahun yang semuannya itu berhubungan dengan bilangan. pemahaman konsep bilangan merupakan sesuatu yang sangat penting khususnya anak usia dini. bilangan merupakan salah satu langkah awal bagi anak untuk pembelajaran konsep matematika awal, tanpa pemahaman akan bilangan, maka anak akan mengalami kesulitan dalam proses pembelajaran di jenjang pendidikan berikutnya. metodologi artikel ilmiah ini dengan jenis penelitian kualitatif, Metode yang digunakan dalam penelitian ini dengan pendekatan literature (library research). pendekatan studi literature merupakan penelitian yang serangkaian kegiatannya dengan metode pengumplan data pustaka, buku-buku, serta tulisan yang terkait dengan judul penelitian ini dari pustaka kamus online (contoh Wikipedia) dan dari internet yang dapat memperkuat naskah yang akan dipublikasikan.
\end{abstract}

Kata Kunci: Kemampuan mengenal lambang bilangan 1-10, Media gelas angka

\begin{abstract}
Abstrak
Implementation of numeric glass media in the developtment of children's cognitif abilities to recognize numbers 1-10 is a study that aims to develop children's understanding of recognizing numbers 1-10. The ability to recognize simbols is a basic ability that must be mastered by children. This is capital for children to know important things in their daily lives related to numbers. Children are ability to recogninize the time, or hour, date month and year all off numbers. Understanding the concept of numbers is something that is very important early childhood. Numbers is the first steps for children to learn early mathematical concepts, without understanding numbers, then the children will experience dificulties in the learning and a process at the next level of education. The methodology is a qualitative research, the method used a literature approach is a research series of activities with the method of collecting and writing related to the title of this research from the online dictionary library (wikipedia) and from which can strengthen the article has published.
\end{abstract}

Keywords: The ability to recognize the symbol 1-10, The Number Glass Media. 


\section{PENDAHULUAN}

Anak usia dini adalah individu yang sedang mengalami proses pertumbuhan dan perkembangan yang sangat pesat atau yang sering kita kenal sebagai golden age(masa keemasan) yaitu usia sangat berharga dibandingkan usia selanjutnya. Masa emas pada anak hanya datang sekali seumur hidup dan tidak dapat diulang. Karena pada masa golden age apa yang dilihat,dirasakan dan dilakukan anak akan tertanam pada memori jangka panjangnya. Menurut Undang-undang Nomor 20 tahun 2003 tentang Sistem Pendidikan Nasional Pasal 1 Ayat 14 menyatakan bahwa Pendidikan anak usia dini adalah suatu upaya pembinaan yang ditujukan pada anak usai 0-6 Tahun melalui pemberian rangsangan pendidikan untuk membantu pertumbuhan dan perkembangan jasmani dan rohani agar anak memiliki kesiapan dalam memasuki pendidikan lebih lanjut.

Pendidikan anak usia dini pada dasarnya meliputi seluruh upaya dan tindakan yang dilakukan oleh pendidik dan orang tua dalam proses merawat,mengasuh, dan pendidikan yang diberikan pada anak dengan menciptakan lingkungan dimana anak dapat mengeksplorasi pengalaman yang memberikan kesempatan kepadanya untuk mengatahui dan memahami pengalaman belajarnya yang diperolehnya dari lingkungan, dengan cara mengamati,meniru,dan bereksperimen yang berlangsung secara berulang-ulang dan melibatkan seluruh potensi dan kecerdasan anak.agar anak dapat tumbuh dan berkembang sesuai dengan tahapan perkembangan anak diperlukannya stimulasi atau rangsangan. Stimulasi merupakan pemberian rangsangan untuk melatih seluruh aspek.Dalam menstimulasi perkembangan anak, orang tua sangat berperan penting. karena pendidikan yang pertama kali diterapkan pada anak adalah keluarga. selain orang tua, lingkungan juga sangat berperan penting dalam menstimulasi perkembangan anak oleh sebab itu lingkungan salah satu pengaruh terbesar bagi anak untuk menentukan jati dirinya.

Terdapat enam aspek perkembangan yang dikembangkan dalam diri anak usia dini meli puti: aspek perkembangan moral dan agama, aspek perkembangan fisik motorik, aspek perkem bangan kognitif, aspek perkembangan bahasa, aspek perkembangan sosial emosional, aspek perkembangan seni. Dari keenam aspek perkembangan yang paling berpengaruh pada anak adalah aspek perkembangan kognitif. Perkembangan kognitif adalah suatu proses berpikir berupa kemampuan untuk menghubungkan, menilai dan mempertimbangkan sesuatu. Dapat juga dimaknai sebagai kemampuan untuk memecahkan masalah atau untuk atau untuk mencipta karya yang dihargai dalam suatu kebudayaan (Depdiknas,2007) Menurut Suardiman (2003) "kemampuan Kognitif sering diartikan sebagai daya atau kemampuan seseorang untuk berfikir dan mengamati melihat hubungan-hubungan kegiatan yang mengakibatkan seseorang anak untuk memperoleh pengatahuan baru yang banyak didukung oleh kemampuan bertanya."

Aspek perkembangan kognitif yang harus dicapai oleh anak usia 4-5 tahun adalah anak mampu membilang banyak benda satu sampai sepuluh, mengenal konsep bilangan, mengenal lambang bilangan dan mengenal lambang huruf. Untuk mengembangkan aspek perkembangan kognitif dalam mengenal lambang bilangan, guru harus berperan aktif dalam membantu anak untuk dapat memahami konsep suatu bilangan. Pertama kali mengenalkan pemahaman konsep bilangan dapat dilakukan sejak anak usia dini dari lingkungan sekitar dan pengalaman sehari hari anak serta memberikan stimulus yang mendukung. Pentingnya mengembangkan kemampuan dalam bidang matematika, yang salah satunya yaitu kemampuan mengenal lambang bilangan 1-10 pada anak usia dini.

Kemampuan mengenal lambang bilangan merupakan kemampuan dasar yang harus dikuasai oleh anak. Hal ini merupakan modal awal bagi anak untuk mengenal hal-hal penting dalam kehidupan sehari-hari khususnya yang berhubungan dengan bilangan. Anak mampu mengenal waktu atau jam,tanggal,bulan, serta tahun yang semuanya itu berhubungan dengan bilangan. Depdiknas (2007) mengemukakan bahwa ciri-ciri yang menandai bahwa anak usia dini mulai menyenangi pembelajaran membilang antara lain, a). Secara spontan telah 
menunjukkan ketertarikan pada aktivitas pembelajaran dengan bilangan; b). Anak mulai menyebutkan urutan bilangan tanpa pemahaman; c). Anak mulai menghitung benda yang ada disekitarnya secara spontan; d). Anak mulai membanding-bandingkan benda-benda dan peristiwa yang ada disekitarnya; e). Anak mulai menjumlah-jumlahkan atau mengurangi angka dan benda yang ada disekitarnya tanpa disengaja.

Pengenalan dini tentang konsep bilangan perlu dilakukan sejak dini untuk menjaga agar tidak terjadi masalah kesulitan belajar karena belum menguasai konsep berhitung. Bilangan adalah suatu obyek matematika yang sifatnya abstrak dan termasuk kedalam unsur yang tidak didefinisikan. Untuk menyatakan suatu bilangan dinotasikan dengan lambang bilangan yang disebut angka Perkembangan matematika dapat dilihat dari kemampuan anak dalam konsep bilangan, menghitung batas tertentu dan bahkan ada yang telah dapat melalukan operasi hitung secara sederhana.

Proses pembelajaran yang dapat menarik perhatian anak untuk mengembangkan kognitifnya adalah proses pembelajaran yang menggunakan media. media adalah segala alat fisik yang dapat menyajikan pesan serta merangsang anak untuk belajar. Melihat dari masalah yang sering terjadi di PAUD , maka perlu dilakukan pembelajaran yang menggunakan media, salah satunya yang menggunakan media gelas angka. Media gelas angka merupakan media dari gelas plastik yang terdiri dari berbagai macam warna sehingga media ini menarik minat anak untuk belajar, dan yang paling penting tidak berbahaya bila dipakai untuk pembelajaran bagi anak. Agar anak mencapai perkembangan yang optimal maka metode pembelajaran yang digunakan harus semenarik mungkin agar ketika anak belajar ia cenderung tidak merasa bosan. Oleh karena itu guru dituntut untuk mengemas pembelajaran semenarik mungkin ,serta daya dukung alat peraga atau media yang digunakan dapat menarik minat dan motivasi belajar peserta didik dalam dunia PAUD.

\section{HASIL DAN PEMBAHASAN}

\section{A. Deskripsi Konseptual}

\section{Tinjauan Perkembangan Kognitif AUD}

a. Perkembangan Kognitif AUD

Kognitif adalah suatu proses berpikir, yaitu kemampuan individu untuk menghubungkan, menilai, dan mempertimbangkan suatu kejadian atau peristiwa.

Menurut Witherington (dalam Sujiono, 2008) kognitif adalah pikiran, kognitif (kecerdasan pikiran) melalui pikiran dapat digunakan dengan cepat dan tepat untuk mengatasi suatu situasi untuk memecahkan masalah.Sedangkan pengertian kognitif menurut Susanto (2011) adalah bagian dari otak, digunakan untuk pemahaman, penalaran, pengatahuan, dan pengertian. Vygotsky (dalam Sujiono:2008) berpikiran bahwa kecerdasan seseorang dapat dimengerti dari latar belakang sosial budaya dan sejarahnya

Menurut Bruner (dalam Martini Jamaris, 2013), proses perkembangan kognitif berlangsung sejalan dengan perkembangan anak. Dalam masa ini,terjadi beberapa transisi perkembangan kognitif. Perkembangan kognitif menurut Bruner adalah perkembangan kemampuan berpikir yang berlangsung secara setahap demi setahap. Perkembangan kemampuan berpikir tersebut memerlukan interaksi antara kamampuan yang ada dalam diri manusia dengan ligkungan disekitarnya dan berlangsung dalam waktu yang panjang.

Berdasarkan uraian di atas disimpulkan bahwa kognitif merupakan salah satu kecerdasan berpikir yang dipakai untuk mengatasi suatu situasi untuk memecahkan masalah. Kognitif merupakan bagian dari otak untuk pemahaman, penalaran, pengatahuan dan pengertian. Namun perkembangan kemampuan berpikir tersebut berlangsung berjalan secara setahap demi setahap. 
b. tahap-tahap perkembangan kognitif pada anak usia dini

Piaget (dalam C. Asri Budiningsih, 2008) menyatakan bahwa perkembangan kognitif merupakan suatu proses genetik, yaitu suatu proses yang didasarkan atas mekanisme biologis perkembangan syaraf.daya pikir atau kekuatan mental anak yang berbeda usia akan berbeda pula secara kualitas.

Piaget membagi tahap-tahap perkembangan kognitif ini menjadi empat yaitu:

a) Tahap sensorimotor (umur 0-2 tahun)

Pertumbuhan kemampuan anak tampak dari kegiatan motorik dan presepsinya yang sederhana. Ciri pokok perkembangannya berdasarkan tindakan,dan dilakukan langkah demi langkah.Kemampuan yang dimilikinya antara lain:

1) Melihat dirinya sendiri sebagai makhluk yang berbeda dengan objek disekitarnya.

2) Mencari ransangan melalui sinar lampu dan suara.

3) Suka memperhatikan sesuatu lebih lama.

b) Tahap praoperasional (umur 2-7 tahun)

Ciri perkembangan pada tahap ini adalah pada penggunaan simbol atau bahasa tanda, dan mulai berkembangnya konsep-konsep intiuitif.pada tahap ini dibagi menjadi dua, yaitu praoperasional dan intiuitif. Praopersaional (umur 2-4 tahun), anak telah mampu menggunakan bahasa dalam mengembangkan konsepnya, walaupun masih sangat sederhana. Karakteristik tahap ini adalah:

1) Self counteranak sangat menonjol.

2) Tidak mampu memusatkan perhatian pada objek-objek yang bebeda.

3) Mampu mengumpulkan barang-barang menurut kriteria.

4) Dapat menyusun benda-benda secara berderet tapi tidak mampu menjelaskan perbedaan antara deretan.

Tahap intiuitif terjadi pada anak yang berumur 4-7 atau 8 tahun. Pada tahap ini anak sudah mulai berpikir abstrak. Anak telah mampu mengungkapkan isi hatinya secara simbolik. Adapun karakteristik tahap intiuitif menurut piaget (dalam C.Asri Budiningsih, 2005) adalah:

1) Anak dapat membentuk kelas-kelas atau kategori objek,tetapi kurang didasari. Anak dapat memecahkan suatu permasalahan yang dihadapi, tetapi anak tidak mampu menjelaskan alasan yang tepat untuk menyelesaikan masalah tersebut.

2) Anak mulai mengatahui hubungan secara logis terhadap hal-hal yang lebih kompleks, tetapi proses pemikiran dan penalaran masih memiliki keterbatasan.

3) Anak dapat melakukan sesuatu terhadap jumlah ide.

4) Anak mampu memperoleh prinsip-prinsip secara benar. Anak mampu mengerti terhadap sejumlah objek yang teratur dan cara mengelompokkannya.

c) Tahap operasional konkret (7-11 tahun)

Tahap ini terjadi pada anak usia 7-11 tahun. Adapun ciri-ciri tahap operasional konkret adalah:

1) Anak sudah mulai menggunakan aturan-aturan yang jelas dan logis.

2) Anak memiliki kecakapan berpikir logis dengan benda-benda konkret.

3) Berpikir menggunakan model kemungkinan.

4) Dapat menggunakan hasil yang telah dicapai sebelumnya.

5) Anak mampu menangani sistem klasifikasi.

d) Tahap operasional formal (umur 11-18 tahun) 
Ciri pokok pada tahap perkembangan ini adalah anak sudah mampu berpikir abstrak dan logis dengan menggunakan pola berpikir "kemungkinan". Anak mampu menarik kesimpulan, menafsirkan dan mengembangkan hipotesa. Adapun karakteristik berpikir anak pada tahap operasional formal adalah:

1) Bekerja secara efektif dan sistematis.

2) Menganalisis sesuatu masalah secara kombinasi.

3) Berpikir secara proposional.

4) Dapat menarik generalisasi secara mendasar pada satu macam isi.

Berdasarkan uraian diatas dapat disimpulkan bahwa perkembangan kognitif anak usia dini pada tahap sensorimotor berbeda dengan tahap yang dialami anak pada tahap praoperasional, dan akan berbeda pula dengan anak yang sudah berada pada tahap operasional konkret,bahkan dengan anak yang sudah pada tahap operasional formal.semakin tinggi tahap perkembangan kognitif seseorang akan semakin teratur dan semakin abstrak cara berpikirnya.

\section{Tinjauan Kemampuan Mengenal Lambang Bilangan pada AUD}

a. Pengertian Lambang Bilangan

Lambang adalah suatu sebagai tanda, huruf atau benda yang digunakan untuk menyampaikan maksud atau pesan. Sedangkan Bilangan adalah jumlah yang menunjukkan banyaknya benda. Bilangan menurut Kamus Besar Bahasa Indonesia Edisi Ketiga (2005) adalah jumlah atau banyaknya benda atau satuan jumlah. Bilangan merupakan Konsep Matematika yang sangat penting untuk dikuasai oleh anak,karena menjadi dasar bagi penguasaan konsep-konsep matematika selanjutnya dijenjang pendidikan (formal) berikutnya.

Hartnett dan gelman (dalam Seefeld \& Wasik, 2008) menyatakan salah satu konsep matematika yang paling penting dipelajari anak ialah pengembangan kepekaan pada bilangan. Peka pada bilangan belarti lebih dari sekedar menghitung tapi mencakup pengembangan rasa kuantitas dan pemahaman kesesuaian satu lawan satu. Pengenalan lambang bilangan tidak hanya sekedar mengenalkan lambang dari suatu bilangan,akan tetapi anak mampu mengatahu makna atau nilai dari suatu bilangan.

Menurut Caufield (dalam Seefeld \& Wasik, 2008) bilangan merupakan bagian dari belajar tata cara berhitung dan juga bagian dari pengalaman anak-anak sehari-hari.

Dari uraian diatas dapat disimpulkan bahwa lambang bilangan merupakan konsep matematika yang sangat penting untuk dikuasai AUD, karena menjadi dasar bagi penguasaan konsep-konsep matematika selanjutya dijenjang pendidikan (formal)berikutnya.

1) Kemampuan Mengenal Konsep Bilangan dan Lambang Bilangan Pada Anak Usia 4-5 tahun

Piaget (dalam Slamet Suyanto, 2005) menyatakan bahwa anak TK berada pada fase perkembangan Praoperasional menuju ke Konkret. Anak pada fase ini belajar dari benda nyata. Oleh sebab itu, orang tua dan guru sangat berperan penting dalam mengenalkan lambang bilangan pada anak dengan menggunkan benda-benda yang ada disekitar kita untuk mengajarkan anak untuk melatih anak berhitung, berpikir logis dan matematis. Proses belajar seorang anak mengikuti pola dan tahap-tahap perkembangan sesuai dengan umurnya. 
Pada dasarnya setiap anak dianugrahi kecerdasan matematis-logis. Matematis - logis adalah kemampuan untuk menangani bilangan dan perhitungan, pola pikir logis dan ilmiah. Gardner (dalam Suyadi, 2010) menyatakan bahwa kecerdasan Matematis - Logis mempunyai beberapa aspek, seperti kemampuan berpikir logis, memecahkan masalah, pola pikir deduktif induktif,kemampuan mengenal pola dan hubungan,berhitung.

Prinsip dan standar untuk matematika sekolah yang dikemukakan oleh kelompok pendidik dari National Council of Teachers of Matehematics (dalam Seefeldet \& Wasik,2008) memaparkan harapan-harapan bagi matematika untuk anak usia empat dan lima tahun. Konsep-konsep yang bisa dipahami anak-anak yaitu:

a) Bilangan : salah satu konsep matematika yang paling penting dipelajari anak-anak usia tiga,empat dan lima tahun ialah pengembangan kepekaan pada bilangan. Ketika kepekaan terhadap bilangan anak-anak berkembang,mereka menjadi semakin tertarik pada hitung-menghitung.

b) Aljabar : aljabar dimulai dengan menyortir, menggolongkan, membandingkan, dan menyusun benda-benda menurut bentuk, jumlah dan sifat-sifat lain.

c) Penggolongan : penggolongan (klasifikasi) yaitu mengelompokkan bendabenda yang serupa atau memiliki kesamaan,ini merupakan proses yang penting untuk mengembangkan konsep bilangan.

d) Membandingkan : adalah proses dimana anak-anak membangun suatu hubungan antara dua benda berdasarkan suatu atribut tertentu.

e) Menyusun : menyusun atau menata adalah tingkat lebih tinggi dari perbandingan. Perbandingan melibatkan benda-benda yang lebih banyak dari dua atau lebih dari dua, dan mencakup menempatkan benda-benda dalam suatu urutan.

f) Pola-pola : kegiatan yang memungkinkan anak-anak membangun pola dari manik-manik dan balok-balok akan menopang perkembangan keterampilan ini.

g) Geometri : membangun konsep geometri pada anak-anak dimulai dengan mengidentifikasi bentuk-bentuk dan menyelediki bangunan dan memisahkan gambar-gambar biasa seperti segi empat,lingkaran,segi tiga.

h) Pengukuran : minat dan kemampuan anak-anak untuk menggunakan pengukuran berkembang dari pengalaman-pengalaman dengan penggolongan, pembandingan dan menyusun.

Kegiatan berhitung yang diberikan pada anak dengan berbagai macam permainan tentunya akan lebih efektif karena bermain bagi anak adalah wahana mereka saat belajar dan bereksplorasi.

Berdasarkan uraian diatas disimpulkan bahwa pengenalan konsep bilangan dan lambang bilangan diberikan pada anak secara bertahap.diawali dengan menghitung benda konkret.proses belajar diberikan sesuai dengan tahap-tahap menurut tingkat kesulitannya.prinsip dan standar matematika untuk sekolah yang dikembangkan oleh kelopok pendidik dari National Council of Teachers ofMathematic,memaparkan harapan-harapan matematika untuk anak usia tiga,empat dan lima tahun, konsep tersebut adalah bilangan, aljabar,penggolongan ,membandingkan , menyusun, pola-pola, geometri, pengukuran.

2) Langkah-langkah Pembelajaran Mengenal Lambang Bilangan pada Anak TK 
Kegiatan dalam mengenalkan lambang bilangan pada anak dapat melalui berbagai macam cara yang menyenangkan untuk anak.menurut Slamet Suyanto (2005) dengan cara sebagai berikut:

a) Menghitung dengan jari: hampir semua orang berhitung permulaan dengan menggunakan jarinya.guru dapat memulai dengan bertanya berapa banyak jari kita dan berikan kesempatan pada anak untuk menjawab masing-masing jumlah jari tersebut dengan cara memberikan kesempatan pada anak maju kedepan untuk bagaimana ia menemukan hasilnya.

b) Bermain domina: kartu domino berisi lingkaran yang merepresentasikan bilangan dari kosong sampai dua belas. Kartu tersebut baik untuk melatih anak menghitung dan mengenal pola.

c) Berhitung sambil bernyanyi dan berolah raga: pada setiap kegiatan, ajak anak mengkomunikasikan pemahamannya.

d) Menghitung benda-benda: orang tua dan guru dapat melatih anak untuk berhitung dengan menggunakan benda apa saja dan dimana saja.

e) Mengenalkan mata uang: mengenalkan mata uang hal yang paling penting untuk anak TK. Karena anak TK pada umumnya sudah memiliki keberanian untuk membeli makanan dan mainannya.

Seefeldt \& Wasik (2008) menyatakan bahwa pengungkapan berulang pada menghitung akan membantu anak mempelajari nama-nama bilangan dan urutan yang diikuti bilangan itu. Menghitung jumlah anak-anak yang hadir dikelas,menghitung jumlah manik-manik, menghitung jumlah geometri yang diperlukan untuk meronce akan memperkuat hitung-menghitug.

Caufield (dalam seefeldt \& Wasik, 2008) menyatakan bahwa mempelajari nama yang sesuai dengan bilangan juga merupakan bagian dari belajar tata cara berhitung. Bilangan adalah bagian dari pengalaman anak sehari-hari.

Pendapat diatas disimpulkan bahwa mengenalkan bilangan dan lambang bilangan dapat dilakukan dengan berbagai cara diantaranya adalah menghitung dengan jari, bermain domino,berhitung sambil bernyanyi dan berolah raga,menghitung benda-benda, dan mengenalkan mata uang.

\section{Tinjauan Media Gelas Angka}

\section{a. Pengertian Media}

Menurut Arsyad (2009) "kata media berasal dari bahasa latin medius yang secara harfiah berarti tengah, perantara atau pengantar." Menurut Gearlach \& Ely (dalam arsyad 2009) " media apabila dipahami secara garis besar adalah manusia, materi, atau kejadian yang membangun kondisi yang membuat siswa mampu memperoleh pengatahuan, keterampilan, atau sikap." Menurut Hasnida (2014) "media sering diidentikan dengan berbagai jenis peralatan atau sarana untuk menyajikan pesan."

\section{b. Pentingnya Media Untuk Anak Usia Dini}

Menurut Hasnida (2014) Media pembelajaran pada dasarnya merupakan bagian integral dari keseluruhan komponen pembelajaran TK/PAUD. Tanpa media, maka proses pembelajaran tidak akan berjalan dengan efektif. Media pembelajaran untuk anak usia dini sangat penting, karena memiliki nilai-nilai sebagai berikut:

1) Memungkinkan anak berinteraksi secara langsung dangan lingkungannya.

2) Memungkinkan adanya keseragaman atau persepsi belajar pada masing-masing anak. 
3) Membangkitkan motivasi belajar anak.

4) Menyajikan informasi belajar secara konsisten dan dapat diulang atau disimpan menurut kebutuhan.

5) Menyajikan pesan atau informasi belajar secara serempak bagi keseluruhan anak.

6) Mengatasi keterbatasan waktu dan ruang.

7) Mengontrol arah dan kecepatan belajar anak.

\section{c. Gelas Angka}

Media gelas angka merupakan media dari gelas plastik yang terdiri dari berbagai macam warna sehingga media ini menarik minat anak untuk belajar, dan yang paling penting tidak berbahaya bila dipakai untuk pembelajaran bagi anak. Media gelas angka memiliki manfaat dan fungsi sebagai media pembelajaran yang dapat menstimulasi perkembangan kognitif anak dalam mengenal lambang bilangan 1-10. Dikarenakan media gelas angka dirancang sebagai media untuk pembelajaran untuk mengenal lambang bilangan 1-10.

Alat dan bahan media gelas angka

1. Kertas Hvs

2. Gelas Aqua

3. Gunting

4. Spidol

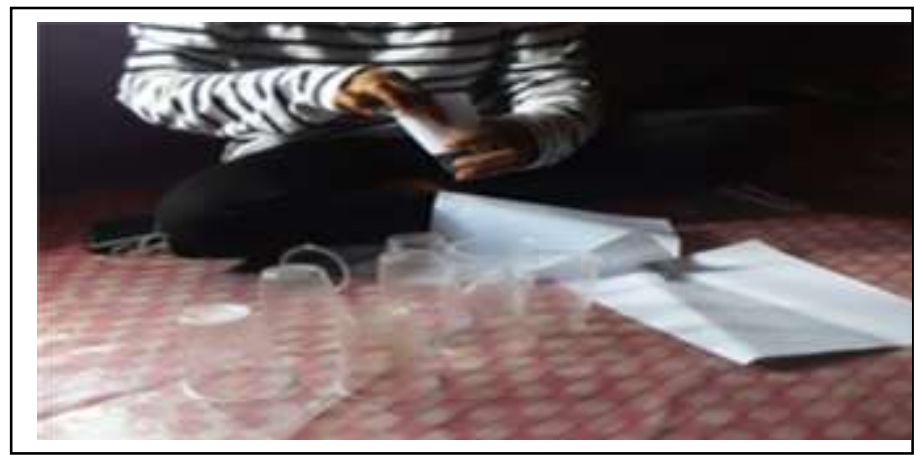

Gambar 1: Cara pembuatan media gelas angka

Cara pembuatan media gelas angka

1. Siapkan gelas aqua yang telah di bersihkan

2. Gunting kertas Hvs yang telah disediakan

3. Masukan guntingan kertas Hvs kedalam gelas

4. Kertas yang sudah di masukan kedalam Gelas ditulis angka secara berurutan sesuai jumlah gelas 


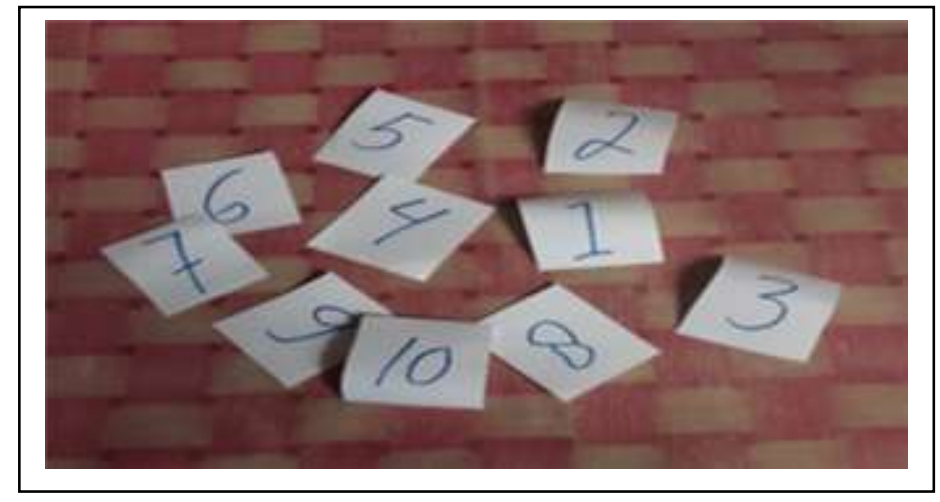

Gambar 2: Pembuatan angka 1-10

\section{Cara pembuatan penomoran angka}

1. Gunting kertas besegi empat ukuranya sesuai keinginan yang dibuat

2. Tulis angka secara berurutan sesuai jumlah kertas yang telah disediakan

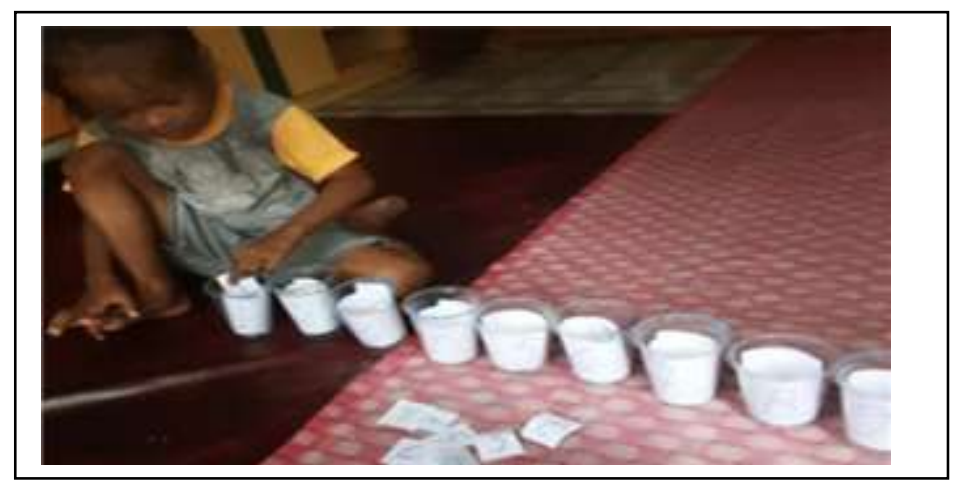

Gambar 3: Kegiatan bermain media gelas angka

Cara bermain media gelas angka

1. Menyusun gelas secara berurutan 1-10

2. Menaruh kertas angka yang telah disediakan kemudian diacak

3. Dilakukan secara individu dan bergantian

4. Anak diberikan kesempatan untuk memilih angka yang telah diacak

5. Angka yang telah dipilih dimasukan kedalam gelas sesuai angka yang diambil

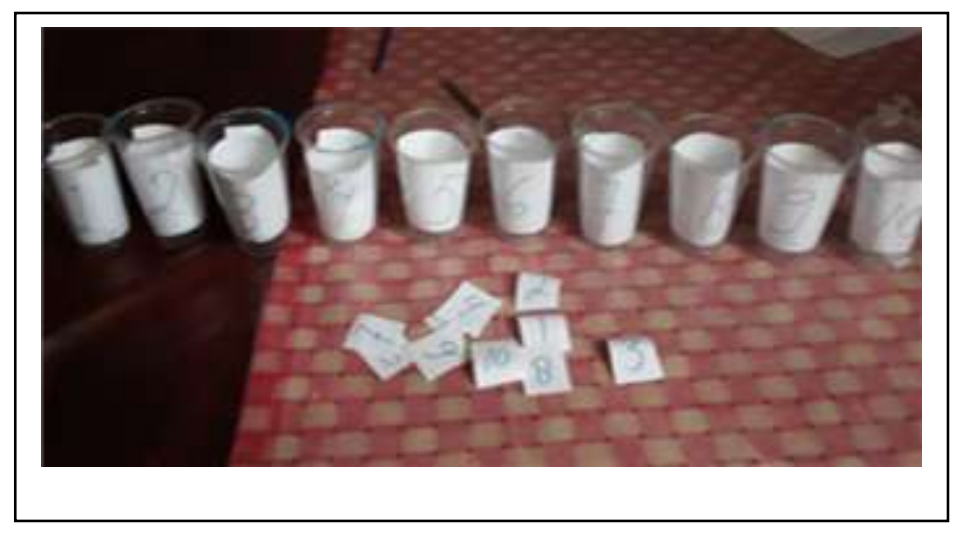

Gambar 4: Kelebihan media gelas angka 
Kelebihan dari Gelas Angka yaitu:

a. Dapat merangsang anak untuk belajar mengenal lambang bilangan.

b. Media ini merupakan media konkrit yang dapat dimainkan anak secara langsung sehingga anak memiliki pengalaman yang dapat membantu mengembangkan pemikiran mereka dalam menyelesaikan permainan yang menggunakan gelas angka tersebut.

c. Dan yang paling penting media ini tidak berbahaya bila dipakai untuk pembelajaran bagi anak.

Kisi-kisi instrumen penelitian observasi kemampuan mengenal lambang bilangan dapat dilihat pada tabel berikut:

Tabel 1. Kisi-kisi instrumen kemampuan mengenal lambang bilangan

\begin{tabular}{|l|l|}
\hline \multicolumn{1}{|c|}{ Variabel } & \multicolumn{1}{|c|}{ Indikator } \\
\hline Kemampuan kognitif berupa kemampuan mengenal & - Membuat urutan \\
lambang bilangan & bilangan 1-10 dengan \\
benda (gelas pelastik) \\
- Menunjuk lambang \\
bilangan 1-10 \\
- Menghubungkanatau \\
memasangkan \\
lambang bilangan \\
dengan benda-benda \\
sampai 10 (anak tidak \\
disuruh menulis)
\end{tabular}

Tabel 1 diatas menunjukan kisi-kisi instrumen penelitian observasi kemampuan mengenal lambang bilangan. Kisi-kisi instrumen meliputi variabel dan indikator. Indikator-indikator tersebut dijabarkan kedalam rubik penilaian. Rubik penilaian dari indikator yang pertama yaitu membuat urutan bilangan 1-10 dengan benda dapat dilihat dalam tabel 2 dibawah ini:

Tabel 2. Rubrik penilaian kemampuan membuat urutan bilangan 1-10 dengan benda

\begin{tabular}{|l|c|l|}
\hline \multicolumn{1}{|c|}{ Kriteria } & Skor & \multicolumn{1}{|c|}{ Keterangan } \\
\hline $\begin{array}{l}\text { Membuat } \\
\text { urutan } \\
\text { bilangan } \\
1-10 \\
\text { dengan } \\
\text { benda }\end{array}$ & 3 & $\begin{array}{l}\text { Jika anak mampu membuat bilangan 1-10 dengan benda } \\
\text { secara tepat dan mandiri }\end{array}$ \\
\hline & 2 & $\begin{array}{l}\text { Jika anak mampu membuat urutan bilangan 1-10 dengan } \\
\text { benda dengan dibimbing }\end{array}$ \\
\hline & 1 & Jika anak belum mampu membuat urutan bilangan 1-10 \\
\hline
\end{tabular}




\begin{tabular}{|l|l|l|}
\hline & dengan benda walau sudah dibimbing \\
\hline
\end{tabular}

Tabel 3. Rubrik penilaian kemampuan menunjuk lambang bilangan 1-10

\begin{tabular}{|l|c|l|}
\hline \multicolumn{1}{|c|}{ Kriteria } & Skor & \multicolumn{1}{|c|}{ Keterangan } \\
\hline $\begin{array}{l}\text { Menunjuk } \\
\text { lambang } \\
\text { bilangan } \\
1-10\end{array}$ & 3 & $\begin{array}{l}\text { Jika anak mampu menunjuk lambang bilangan 1-10 } \\
\text { secara tepat dan mandiri }\end{array}$ \\
\hline & 2 & $\begin{array}{l}\text { Jika anak mampu menunjuk lambang bilangan 1-10 } \\
\text { secara tepat dengan bimbingan }\end{array}$ \\
\hline & 1 & $\begin{array}{l}\text { Jika belum mampu menunjuk lambang bilangan 1-10 } \\
\text { walau sudah dibimbing }\end{array}$ \\
\hline
\end{tabular}

Tabel 4. Rubrik penilaian kemampuan memasangkan lambang bilangan dengan bendabenda sampai 10

\begin{tabular}{|l|c|l|l|}
\hline \multicolumn{1}{|c|}{ Kriteria } & Skor & \multicolumn{1}{|c|}{ Keterangan } & \\
\hline $\begin{array}{l}\text { Memasangkan } \\
\text { lambang } \\
\text { bilangan } \\
\text { dengan } \\
\text { benda-benda } \\
\text { sampai 10 } \\
\text { (anak tidak } \\
\text { disuruh } \\
\text { menulis) }\end{array}$ & 3 & $\begin{array}{l}\text { Jika anak mampu memasangkan lambang bilangan } \\
\text { dengan benda-benda sampai 10 secara tepat dan } \\
\text { mandiri }\end{array}$ \\
\hline & 2 & $\begin{array}{l}\text { Jika anak mampu memasangkan lambang bilangan } \\
\text { dengan benda-benda sampai 10 dengan bimbingan }\end{array}$ \\
\hline & 1 & $\begin{array}{l}\text { Jika anak belum mampu memasangkan lambang } \\
\text { bilangan dengan benda-benda sampai 10 walau } \\
\text { sudah dibimbing }\end{array}$ \\
\hline
\end{tabular}

\section{B. Metodologi Penelitian}

Metode yang digunakan dalam penelitian ini dengan pendekatan literature (library research). Menurut Zed Mestika (2004) menyatakan bahwa metode penelitian ini dengan pendekatan studi literature merupakan penelitian yang serangkaian kegiatannya dengan metode pengumplan data pustaka, buku-buku, serta tulisan yang terkait dengan judul penelitian ini dari pustaka kamus online (contoh Wikipedia) dan dari internet yang dapat memperkuat naskah yang akan dipublikasikan. 


\section{KESIMPULAN}

Berdasarkan dari rangkaian pembahasan dan permasalahan yang terjadi dapat disimpulkan bahwa:

1. Media gelas angka merupakan media dari gelas plastik yang terdiri dari berbagai macam warna sehingga media ini menarik minat anak untuk belajar, dan yang paling penting tidak berbahaya bila dipakai untuk pembelajaran bagi anak. Kelebihan media gelas angka: 1) dapat merangsang anak untuk belajar mengenal lambing bilangan 2) media ini merupakan media konkrit yang dapat dimainkan anak secara langsung sehingga anak memiliki pengalaman yang dapat membantu mengembangkan pemikiran mereka dalam menyelesaikan permainan yang menggunakan angka tersebut 3) media ini tidak berbahaya ketika dipakai anak dalam proses pembelajaran.

2. kognitif merupakan salah satu kecerdasan berpikir yang dipakai untuk mengatasi suatu situasi untuk memecahkan masalah.Kognitif merupakan bagian dari otak untuk pemahaman, penalaran, pengatahuan dan pengertian. Namun perkembangan kemampuan berpikir tersebut berlangsung berjalan secara setahap demi setahap.

3. Mengenalkan lambang bilangan dengan cara yang sederhana dan menyenangkan yaitu: 1) menghitung dengan jari 2) bermain domino 3) berhitung sambil bernyanyi dan berolah raga 4) mengitung benda-benda 5) mengenalkan mata uang. 


\section{DAFTAR PUSTAKA}

Andang Ismail. (2006). Education Games. Yogyakarta: Pilar Media.

Arsyad, A. (2009). Media Pembelajaran. Jakarta: Rajawali Pers.

C. Asri Budiningsih. (2008). Belajar dan Pembelajaran. Jakarta: PT Rineka Cipta.

Departemen Pendidikan Nasional. 2007. Pedoman Pembelajaran Bidang Penembangan Kognitif Di Taman Kanak-kanak Buku: 3 Seri Model Pembelajaran Di TK. Jakarta: Direktorat Jenderal Manajemen Pendiidikan Dasar Dan Menengah Direktorat Pembinaan Taman Kanak-Kanak Dan Sekolah Dasar Eliyawati, Cucu, Pemilihan dan Pengembangan Sumber Belajar untuk Usia Dini. Jakarta: Departemen Pendidikan Nasional.

Hasnida. (2014). Media Pembelajaran Kreatif. Jakarta Timur: PT. Luxima Metro Media.

Kurikulum 2013 PAUD Tahun 2014 tentang Standar Pendidikan Anak Usia Dini.

Kidder Louise, Research Methods in Social Relation, Holt, Rinehart, 1973.

Martini Jamaris. (2013). Orientasi Baru dalam Psikologi Pendidikan. Jakarta: Ghalia Indonesia.

Martini Jamaris. (2005). Perkembangan dan Pengembangan Anak Usia Taman KanakKanak. Jakarta: Grasindo.

Mayke S. Tedjasaputra. (2001). Bermain, Mainan dan Permainan Untuk Pendidikan Usia Dini. Jakarta: Grasindo.

Ngalim Purwanto. (2006). Prinsip-prinsip dan Teknik Evaluasi Pengajaran. Bandung: PT Remaja Rosdakarya.

Pardjono. (2007). Panduan Penelitian Tindakan Kelas. Yogyakarta : Lembaga Penelitian $U N Y$.

Riyanto.(2016).Pengaruh-media-gelas-angka-1-10-terhadap-kemampuankognitifmengenal-lambang-bilangan-kelompok-a-https://docplayer.info/2016-0206/diaksespada 11 Desember 2019

Seefeld, C. \& Wasik, B. (2008). Pendidikan Anak Usia Dini (Alih Bahasa: Plus Nasar). Jakarta : PT Indeks.

Slamet Suyanto (2005a). Dasar-dasar Pendidikan Anak Usia Dini. Jakarta : Departemen Pendidikan Nasional, Direktorat Jenderal Pendidikan Tinggi, Direktorat Pembinaan Pendidikan Tenaga Kependidikan dan Ketenagaan Perguruan Tinggi.

Slamet Suyanto (2005b). Pembelajaran Untuk Anak TK. Jakarta: Hikayat Publishing.

Sugiyono. (2016). Metode Penelitian Kuantitatif, Kualitatif, dan R \& B. Bandung: Alfabeta. 
Sujiono. Yuliani Nuraini, (2008). Metode Pengembangan Kognitif. Jakarta : Universitas Terbuka.

Suyadi. (2010). Psikologi Belajar PAUD. Yogyakarta: Pedagogia.

Santrock. Jhon W.2007. Perkembangan Anak. Jakarta: PT Indeks.

Susanto, Ahmad.2011. Perkembangan Anak Usia Dini. Jakarta: kencana Prenada Media Group

Suardiman, S. P. (2003). Metode Pengembangan Daya Pikir Dan Daya Cipta Untuk Anak Usia Dini Yogyakarta: FIP UNY.

Sudaryanti. (2006). Pengenalan Matematika Anak Usia Dini. Yogyakarta: Fakultas Ilmu Pendidikan Universitas Negeri Yogyakarta.

Zed, Mestika, 2004, Metode Penelitian Kepustakaan. Jakarta: Yayasan Obor Indonesia 